\title{
RESEARCH PAPER \\ Variation over time in the prevalences of three viruses of the grapevine leafroll complex in a commercial vineyard in south-central Chile
}

\author{
María Valentina Mujica', Roxana Mora $^{2}$, Marlene Rosales ${ }^{3}$, and Claudio \\ Sandoval ${ }^{1}$ \\ ${ }^{1}$ Facultad de Ciencias Agrarias, Universidad de Talca. Avenida Lyrcay s/n, Talca, Chile. \\ ${ }^{2}$ Centro Regional de Investigación La Platina, Instituto de Investigaciones Agropecuarias (INIA). Santa \\ Rosa 11610, Santiago, Chile. \\ ${ }^{3}$ Facultad de Agronomía e Ingeniería Forestal, Pontificia Universidad Católica de Chile, Ave. Vicuña \\ Mackenna 4860, Santiago, Chile.
}

\begin{abstract}
M.V. Mujica, R. Mora, M. Rosales, and C. Sandoval. 2013. Variation over time in the prevalence of three viruses of the grapevine leafroll complex in a commercial vineyard in south-central Chile. Cien. Inv. Agr. 40(1):139-147. A vineyard in south-central Chile was surveyed during five growing seasons to analyze the increase over time in the number of plants infected with Grapevine leafroll-associated virus-1, -2 and -3. At the end of the study, GLRaV-3 was found to be the most prevalent virus, with $46 \%$ of plants infected by this pathogen. GLRaV-2 infected $13 \%$ of plants, and GLRaV-1 infected $12 \%$. Considering all three viruses together, the prevalence of infection increased exponentially from $14 \%$ of the plants at the beginning of the study period to $68 \%$ at the end. The patterns of the spread of GLRaV-2 and GLRaV-3 were mostly along the rows, whereas the pattern of spread for GLRaV-1 could not be determined.
\end{abstract}

Key words: Field transmission, Grapevine leafroll-associated virus, GLRaV-1, GLRaV-2, GLRaV-3, virus diagnosis.

\section{Introduction}

Viticulture is one of the most important activities worldwide in terms of, not only the area planted with vineyards but also the amount of money involved in this business in wine-producing countries. Grapes (Vitis vinifera L.) are cultivated

Received March 16, 2012. Accepted June, 26, 2012. Corresponding author: mmujica@utalca.cl in Chile from Copiapó to Temuco, with the highest concentration between the Valparaíso and Maule Regions. In this geographical area, 55,119.4 ha of table grapes and 104,717 ha of grapes for wine production are grown. Chile exports 1,600,000 tons of fresh fruit per year; $40 \%$ of these exports are table grapes, which generate earnings of US\$ 796 million. If wine production is added to this figure, the earnings rise to US\$ 820 million (SAG, 2010). Chile is the largest table grape exporter in 
the southern hemisphere and the second largest worldwide. Its primary markets are the USA, the Netherlands and the United Kingdom. Within Chile, the Maule Region has the largest area of table grape vineyards, with 49,014.17 ha, equivalent to $43.9 \%$ of the total (SAG, 2009).

One of the most important factors affecting fruit quality is the range of pathogens that attack grapevines. Viral diseases constitute a major problem worldwide, affecting both plant development and production quality. More than sixty different viruses can infect Vitis vinifera (Martelli and Boudon-Padieu, 2006), although not all of them are of importance in every region where grapes are cultivated. The Grapevine leafroll-associated virus (GLRaV) complex is present worldwide, and its distribution is associated with the propagation of Vitis plants. Propagation material is harvested during the winter, when the plants do not have leaves and there are no visible signs of infection. The disease causes permanent damage. It has been recently established that some strains of the virus are disseminated in the field by mealybugs (Planococcus sp. and Pseudococcus sp.) (Maeso, 2000; Rosciglione and Gugerli, 1989; Tanne et al., 1989; Gugerli et al., 1991; Minafra and Hadidi, 1994; Sforza et al., 2000). In Chile, the first virus belonging to this complex was identified in 1988 (Arancibia, 1988; Auger et al., 1989).

In the Closteroviridae family, the most important virus in economic terms is GLRaV. Eleven different viruses belonging to this complex have been described worldwide. The most important of these viruses according to the damage they cause are GLRaV- 1, GLRaV-2 and GLRaV-3 (Martelli et al., 2012). The most common effects of infection with this pathogen are reduced productivity, lower sugar content in the fruit, and decreased berry pigmentation (Vega et al., 2011), which have negative consequences for wine production. In Chile, more than fifteen viruses (Fiore et al., 2008) and four phytoplasms (Herrera, 2000) that infect grapevines have been identified, the most frequent being GLRaV and Grapevine fanleaf virus (GFLV) (Latorre, 2004).

In field surveys of GLRaV, GLRaV-2 has been found to be the most frequent strain, with the highest infection levels being found in the Atacama, Coquimbo, and Valparaíso regions (Fiore et al., 2008). Recently, the presence of GLRaV-4 (Escobar et al., 2008), GLRaV-5 (Engel et al., 2010), and GLRaV-7 and 9 has been observed in Chile (Engel et al., 2008).

Although numerous studies focused on these viruses have been performed in Chile, there is little epidemiological information about how the pathogens of this complex spread in the field or about the extent of the increase in the number of infected plants from one season to another (infection rate). To address this gap, a field experiment was performed in a commercial vineyard in southcentral Chile. The primary objective of this study was to analyze the patterns of the spread of three viruses of the grapevine leafroll complex (GLRaV-1, GLRaV-2 and GLRaV-3) in the field. Additionally, the infection rate was estimated over five growing seasons.

\section{Materials and methods}

\section{Plant material}

A total of 100 plants from a commercial vineyard, cv. Cabernet Sauvignon, planted in 1998, were analyzed yearly for the presence of Grapevine leafroll-associated viruses 1, 2, and 3 during five growing seasons (2007-2011). The vineyard was located at the Panguilemo Experimental Station,

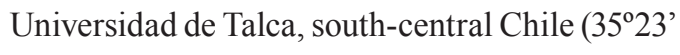
S, 7140’ W, 110 meters above sea level).

\section{Serological assays}

Vine shoots were collected once during the autumn (mid-March) each year and tested using a double 
antibody sandwich enzyme-linked immunosorbent assay (DAS-ELISA) (Clark and Adams, 1977). Commercial polyclonal antibodies and specific conjugates for GLRaV-1, -2 and -3 were obtained from AGDIA Inc. (Indiana, USA). Each sample was tested in duplicate following the protocol recommended by the supplier. Extracts were prepared by macerating $1 \mathrm{~g}$ of phloem tissue in $5 \mathrm{~mL}$ of extraction buffer. The absorbance was measured at $405 \mathrm{~nm}$ using an automatic microplate reader (Wallac 1420, Perkin Elmer). Samples with absorbance readings that exceeded that of the healthy control by three times were considered positive for the presence of the pathogens tested.

\section{Nucleic acid extraction}

Total RNA from each sample was extracted using the method described by Bertheau et al. (1998). The RNA integrity was assessed by electrophoresis on $1 \%$ agarose gels.

\section{$R T-P C R$}

The plants were also tested every year by RT-PCR at the same time as the ELISA was performed using the same samples. Complementary DNA (cDNA) was obtained using MMLV reverse transcriptase (INVITROGEN). The RT reaction was performed with approximately $300 \mathrm{ng}$ of total RNA, $2 \mu \mathrm{L}$ of random primers (10 micro molar), $1 \mathrm{X}$ enzyme buffer, $0.5 \mathrm{mM}$ dNTPs, 10 $\mathrm{mM}$ dithiothreitol (DTT), $20 \mathrm{U}$ of RiboLock ${ }^{\mathrm{TM}}$ RNase Inhibitor (Fermentas) and $100 \mathrm{U}$ of MMLV RT in a final volume of $40 \mu \mathrm{L}$. The reaction was incubated for 10 minutes at $25^{\circ} \mathrm{C}$ and then $1 \mathrm{~h}$ at $37^{\circ} \mathrm{C}$ and was stopped by incubation at $75{ }^{\circ} \mathrm{C}$ for 10 minutes.

Single polymerase chain reaction (PCR) amplification for virus detection was performed using specific primers previously described for GLRaV-2 (Abou Ghanem et al., 2000) and primers designed specifically for GLRaV-1, LR1 F (5'
TTTGGAAGGGTTGGGTAAG 3') and LR1 R (5'TCACGACCACCCAAAAAG 3'), and GLRaV-3, LR3 F (5' CCGTAGTGCCCGAAAAATA 3') and LR3 R (5' AACTCCCGTCAAGTCCAAAG 3'). The thermocycler program consisted of 35 cycles of $94^{\circ} \mathrm{C}$ for $30 \mathrm{sec}, 55^{\circ} \mathrm{C}$ (GLRaV-1 and GLRaV-2) or $53{ }^{\circ} \mathrm{C}(\mathrm{GLRaV}-3)$ for $30 \mathrm{sec}$ and $72{ }^{\circ} \mathrm{C}$ for 40 sec. The PCR products were visualized by $1 \%$ agarose gel electrophoresis and observed under UV light after staining with ethidium bromide.

\section{Results}

A summary of the results obtained from the serological analysis and RT- PCR assays for the GLRaV-1, -2, -3 viruses is presented in Figure 1. The numbers of positive samples for all three viruses analyzed increased over the five seasons. GLRaV-3 was found to be the most prevalent, with a final prevalence of $46 \%$ during the last sampling season. In the cases of GLRaV-1 and GLRaV-2, the final prevalences after the five growing seasons were lower, 12 and 13\%, respectively. All the samples that had positive ELISA results were positive by RT-PCR. In contrast, $5 \%$ of the samples were positive only by RT-PCR. Samples found to be positive using any of the diagnostic techniques were considered positive.

The prevalences of GLRaV-1 and GLRaV-2 changed in a similar (Figure 1) manner, starting with low prevalences during the first season. The prevalences increased quickly during the first season and then increased at slower rates. The number of infected plants stabilized during the last two seasons. The change in the prevalence of GLRaV-3 was similar, as shown in Figure 1; however, the number of infected plants detected was higher for each successive growing season.

The patterns of the spread for these three viruses were predominantly along the rows. The pattern was especially clear for GLRaV-2 and 3, as shown in Figure 1. In the case of GLRaV-1, a clear pattern could not be identified for the spread of 


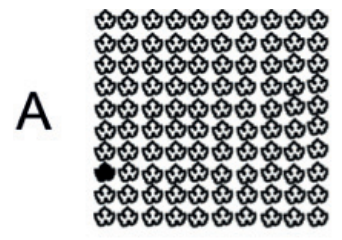

2007

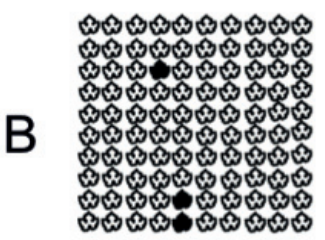

2007

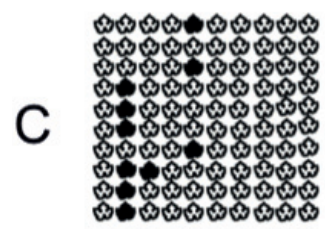

2007

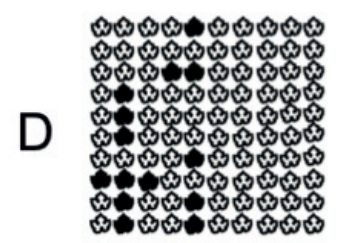

2007

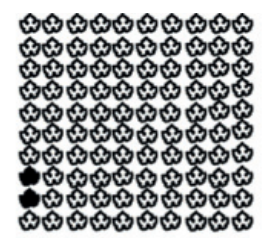

2008

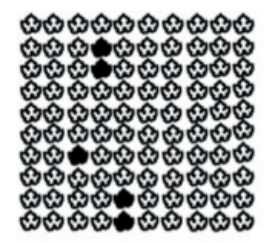

2008

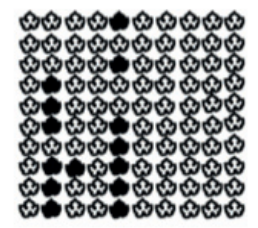

2008

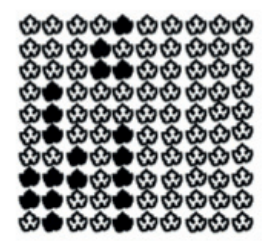

2008

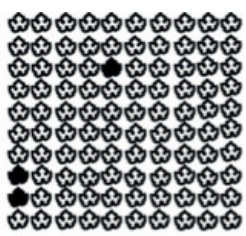

2009

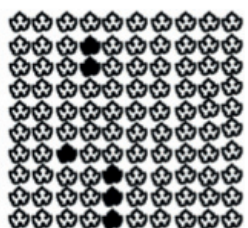

2009

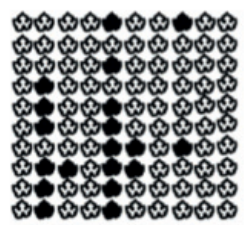

2009

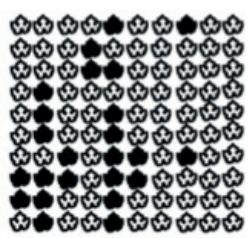

2009

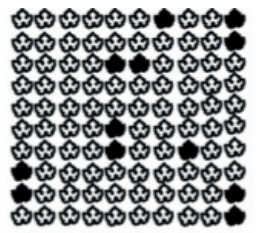

2010

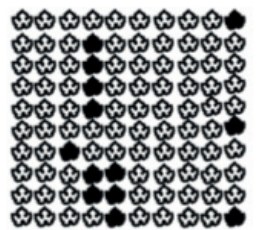

2010

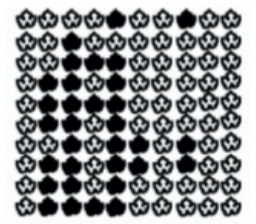

2010

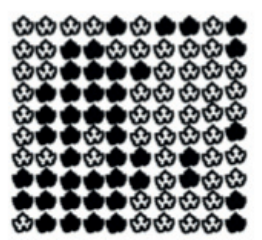

2010

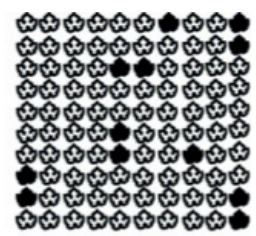

2011

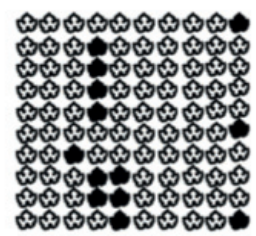

2011

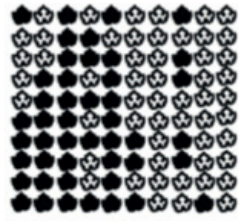

2011

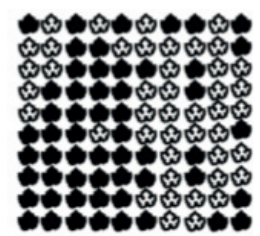

2011

Figure 1. The spread of grapevine leafroll-associated virus during five growing seasons in a commercial vineyard in south-central Chile. A: Grapevine leafroll-associated virus - 1, B: Grapevine leafroll-associated virus - 2, C: Grapevine leafroll-associated virus - 3, D: Grapevine leafroll-associated virus - 1, Grapevine leafroll-associated virus - 2 and Grapevine leafroll-associated virus - 3. Dark plants represent infected plants.

the infection over time due to the small number of infected plants detected and their location. These results may indicate that these viruses move from infected to healthy plants through natural root grafting or are carried by mealybugs. Serological and molecular analysis also detected mixed infections, as shown in Figure 1. During the last growing season in this study, $9 \%$ of the plants were infected with GLRaV-2 and 3, 3.4\% were infected with GLRaV-1 and 2, and 1\% were infected with GLRaV-1 and 3. Simultaneous infection by all three viruses was found in $2 \%$ of the plants.

When the three viruses analyzed were considered together over the five growing seasons, the prevalence in 2007 was $14 \%$ and increased very quickly during the following years to 21, 28, 47 and $68 \%(2008,2009,2010$, and 2011 respectively) (Figure 1).

The presence of signs of infection did not always correlate with virus detection. Ninety-five percent of the samples that tested positive for any of the viruses analyzed came from plants showing signs associated with the leafroll complex, but $5 \%$ of the positive samples were collected from plants without signs of virus infection (results not shown). Most likely, these plants with no signs of infection were latently infected with these viruses. 


\section{Discussion}

As has been reported previously by other researchers around the world, GLRaV-3 was found to be the most prevalent virus of the complex (Ahmed, et al., 2004; Sharma et al., 2011; Rakhshandehroo et al. 2005; Mahfoudhi et al. 2008; Hanna et al. 2008; Martin et al., 2005; Cabaleiro and Segura, 2006; Coetze et al., 2010), followed by GLRAV-2 and GLRaV-1. These results are contrary to those reported by Fiore et al. $(2008,2011)$, who studied other production areas in Chile and found that the most common virus was GLRaV-2. The different results obtained in this study can most likely be explained by the fact that the relative tolerance of table grape cultivars to the virus differs from the level of tolerance of Vitis genotypes used for wine production. It should also be noted that the data presented herein correspond to a single vineyard and are not necessarily representative of the situation in Chile. However, these results agree with the data obtained in other growing areas in different countries.

The fact that GLRaV-1 and GLRaV-2 spread in similar manners, stabilizing the number of the infected plants during the last two seasons, can be explained by two factors. First, these two viruses could have a longer latency period, causing them to go undetected immediately after infection. Second, mealybugs could be a more important vector for GLRaV-1 and GLRaV-2, and during the last two growing seasons, the population of this vector was lower (results not shown).

Rapayati et al. (2009) found infections with two members of the leafroll complex in $13.56 \%$ of the samples collected, similar to the results obtained in this study if we add all the multiple infections observed (GLRaV-1 + GLRaV-2, GLRaV-1 + GLRaV-3 and GLRaV-2 + GLRaV-3) (Table 1). These data suggest that this type of infection, with more than one virus infecting a plant simultaneously, is frequent for this complex in Vitis. Cabaleiro (2009) proposes three types of infection dispersion for leafroll disease. The first type (random pattern) is when a vineyard is established using infected material, and diseased plants are randomly mixed with healthy individuals. In the second type (edge pattern), the viruses are spread from an infected vineyard to healthy plants in their vicinity. Finally, in the third type (row pattern), the transmission of the virus from plant to plant is mediated by vectors that feed on infected plants and then move to healthy plants. In this case, the spread of the infection starts at different points within the vineyard (Rowhani and Golino, 1995: Pietersen, 2004). However, Grasswitz and James (2008) reported that when mealybugs are the only vectors, there is poor dispersal of the virus because of the low transmission efficiency and high mortality of these insects. These authors concluded that if the spread of leafroll disease is based on the activity of this vector alone, the increase in the number of infected plants over time will be low. Even if the mealybugs are associated with ants (Geiger and Daane, 2001), natural root grafting between adjacent plants will remain the most important means of transmission within a vineyard (Epstein, 1978), providing a better explanation for the infection rate observed in the field of this experiment. The final increase in the number of infected plants over time is the result of a combination of all the factors mentioned above. The dispersion rates reported in the literature are different when mealybugs are considered to be the primary vector of the disease. According to Gribaudo et al. (2009), this difference may be related to three factors: first, the species of mealybug involved, given that there are several species that can transmit the disease (Charles et al., 2006); second, the size of the mealybug population present; and third, the size of the infection foci relative to the age of the vineyard (Cabaleiro and Segura, 2003). The results obtained in this study indicate that at least two factors are involved in the spread of these three viruses: root grafting and mealybugs. Given this result, measures to control this disease in the field include vector control, planting certified material, and the eradication of infected plants from the field. 
Table 1. Incidence of Grapevine leafroll-associated virus (GLRaV-1, GLRaV-2 and GLRaV-3) in a commercial vineyard in south-central Chile during five growing seasons (2007-2011). A total of 100 plants were analyzed by ELISA and RT-PCR.

\begin{tabular}{lccccc}
\hline & \multicolumn{5}{c}{ Season } \\
\cline { 2 - 6 } Virus detected & 2007 & 2008 & 2009 & 2010 & 2011 \\
\hline No infection & 86 & 80 & 72 & 43 & 29 \\
Single infection & 1 & 2 & 3 & 12 & 6 \\
GLRaV-1 & 3 & 5 & 4 & 13 & 0 \\
GLRaV-2 & 10 & 14 & 17 & 32 & 34 \\
GLRaV-3 & 14 & 21 & 24 & 47 & 40 \\
Subtotal infected (\%) & & & & & \\
Multiple infection & 0 & 0 & 0 & 1 & 4 \\
GLRaV-1 + GLRaV-2 & 0 & 0 & 0 & 0 & 1 \\
GLRaV-1 + GLRaV-3 & 0 & 0 & 2 & 5 & 9 \\
GLRaV-2 + GLRaV-3 & 0 & 0 & 0 & 1 & 2 \\
GLRaV-1 + GLRaV-2+ GLRaV-3 & 0 & 0 & 2 & 7 & 16 \\
Subtotal infected (\%) & & &
\end{tabular}

One of the factors that can affect the development of signs of infection is the virus titer in the plant tissue, which can change significantly during the sampling period. Although Tsai et al. (2011) did not find any differences in virus concentration when they compared pedicels from apical and basal shoots, pedicels from apical shoots had a higher virus titer early in the season. Later on, the virus concentration reached its maximum independent of the location of the pedicel. Finally, at the end of the growing season, pedicels from apical shoots again had the highest virus concentration. In the case of GLRaV-3 in particular, detection over the growing season is highly dependent on the detection method used. It has been found that the detection rate of this virus complex remains constant when ELISA is used but decreases at the end of the season when RT-PCR is used (Fiore et al., 2009). Given this information, the sampling was performed every year at the same time to avoid significant changes in the virus titer. However, the intensity of infection signs may vary depending on the virus or viruses present. The most severe signs of infection are observed when GLRaV-3 is present alone or in mixed infections that include it (Besse and Gugerli, 2009).

The results obtained in this study indicate that root grafting and mealybugs are the primary modes of spread of these three viruses in the field. However, it is necessary to conduct further research on vector dynamics in the vineyard, the presence of other viruses in the plants and the interactions of these pathogens with GLRaV-1, 2 and 3.

\section{Resumen}

M.V. Mujica, R. Mora, M. Rosales y C. Sandoval. 2013. Variación temporal en la detección de tres virus del complejo del enrollamiento de la hoja de la vid en una viña comercial del área centro-sur de Chile. Cien. Inv. Agr. 40(1):139-147. Un viñedo de la zona centro - sur de Chile fue monitoreado durante cinco temporadas con el objetivo de analizar el desarrollo de la epidemia de Grapevine leafroll-associated virus - 1, 2, y 3. Al final del tiempo de evaluación el GLRaV-3 resultó ser el virus más prevalente con un 46\% seguido del GLRaV-2 con 13\% y GLRaV-1 con $12 \%$. Considerando los virus en su conjunto, la infección 
avanzó rápidamente de un 14\% inicial de plantas afectadas a un $68 \%$ al final del período. El patrón de diseminación de la epidemia fue fundamentalmente en el sentido de la hileras del viñedo para los virus GLRaV-2, y -3, mientras que para GLRaV-1 no pudo ser determinado.

Palabras clave: Diagnóstico de virus, diseminación de campo, GLRaV-1, GLRaV-2, GLRaV-3.

\section{References}

Abou Ghanem - Sabanadzovic N., S. Sabanadzovic, M.A. Castellano, D. Boscia, and G.P. Martelli. 2000. Properties of a new isolate of GLRaV-2. Vitis 39:119-121.

Ahmed, H., M. Digiago, and G.P. Martelli. 2004. Viruses and virus diseases of grapevine in Egypt. Bulletin OEPP/EPPO. Bulletin 34:395-398.

Arancibia, M. 1988. Identificación de los virus asociados al enrollamiento de la hoja de la vid ( $V$. vinifera L.) presentes en el cv. Black seedless y la obtención de plantas limpias mediante termoterapia y cultivo de meristemas. Tesis Ingeniero Agrónomo. Universidad de Chile, Facultad de Agronomía. Santiago, Chile. 100 pp.

Auger, J., R. Arancibia, and P. Gugerli. 1989. Isolation and identification of virus particles in leafroll infected grapevines in Chile. p. 95. In: Tanne, E. (ed.). Proceedings of the 9th Meeting of the International Council for the Study of Viruses and Virus Diseases of the Grapevine (ICGV), Kiryat Anavim, Israel, September 1987. The Volcani Center, P.O. Box 6, Bet Dagan 50250, Israel.

Bertheau Y., D. Fréchon, L.J. Hyman, and I.K. Toth. 1998. E. c. atroseptica DNA amplification by polymerase chain reaction (PCR). In: Pérombelon M.C.M., and J.M. van der Wolf (eds.). Methods for Detection and Quantification of Erwinia carotovora subsp. atroseptica on Potatoes: A Laboratory Manual. Occasional Publication No. 10. Dundee, UK: Scottish Crop Research Institute. p. 39-59.

Besse, S., and P. Gugerli. 2009. Survey of major grapevine virus diseases in the vineyard of Valais (Switzerland). Highlights of the 16th Meeting of ICVG Dijon, France, 31 August - 4 September.

Cabaleiro, C., and A. Segura. 2003. Monitoring the field spread of Grapevine leafroll-associated virus
3 for 12 years. Extended Abstracts $14^{\text {th }}$ Meeting of ICVG, Locorotondo 2003. p. 216-217.

Cabaleiro, C., and A. Segura. 2006. Temporal analysis of Grapevine leafroll-associated virus 3 epidemics. European Journal of Plant Pathology 114:441-446.

Cabaleiro, C. 2009. Current advances in the epidemiology of grapevine leafroll disease. Highlights of the 16th Meeting of ICVG Dijon, France, 31 August - 4 September.

Charles, J., D. Cohen, J. Walker, S. Forgie, V. Bell, and K. Breen. 2006. A review of the ecology of grapevine leafroll associated virus type 3 (GLRaV-3). New Zealand Plant Protection 59:330-337.

Clark, M.F., and A.N. Adams. 1977. Characteristics of the microplate method of enzyme-linked immunosorbent assay for the detection of plant viruses. Journal of General Virology 34: 475-483.

Coetze, B., M. Freeborough, H. Maree, J. Celton, D. Rees, and J. Burger. 2010. Deep sequencing analysis of viruses infecting grapevines: virome of a vineyard. Virology 400:157-163.

Engel, E., P. Escobar, P. Rivera, and P. Valenzuela. 2010. First report on the occurrence of Grapevine leafroll-associated virus 5 in Chilean grapevines. Plant Disease 94:1067.

Engel, E., P. Escobar, C. Montt, S. Gómez-Talquenca, and P.D.T. Valenzuela. 2008. First report on the occurrence of grapevine leafroll-associated virus 7 and 9 in Chilean grapevines. Plant Disease 92:1252.

Epstein, A. 1978. Root graft transmission of tree pathogens. Annual Reviews of Phytopathology 16:181-192.

Escobar, P., N. Fiore, P. Valenzuela, and E. Engel. 2008. First detection of grapevine leafroll-associated 
virus 4 in Chilean grapevines. Plant Disease 92:1474.

Fiore, N., A. Zamorano, L. Rivera, F. González, E. Aballay, and J. Montealegre. 2011. Grapevine viruses in the Atacama Region of Chile. Journal of Phytopathology 159:743-750.

Fiore, N., S. Prodan, and A. Pino. 2009. Monitoring grapevine viruses by ELISA and RT-PCR throughout the year. Journal of Plant Pathology 91:489-493.

Fiore, N., S. Prodan, J. Montealegre, E. Aballay, A. Pino, and A. Zamorano. 2008. Survey of grapevine viruses in Chile. Journal of Plant Pathology 90:125-130.

Geiger, C., and K. Daane. 2001. Seasonal movement and distribution of the grape mealybug (Homoptera: Pseudococcidae): developing a sampling program for San Joaquin valley vineyards. Journal of Economic Entomology 94:291-301.

Grasswitz, T., and D.James, D. 2008. Movement of grape mealybug, Pseudococcus maritimus, on and between host plants. Entomologia Experimentalis et Applicata 129:268-275.

Gribaudo, I., G. Gambino, S. Bertin, D. Bosco, A. Cotroneo, and F. Mannini. 2009. Monitoring the spread of viruses after vineyard replanting with heat-treated clones of Vitis vinifera "Nebbiolo" Journal of Plant Pathology 91:741-744.

Gugerli, P., B. Rosciglione, J. Brugger, S. Bonnard, M. Ramel, and F. Tremea. 1991. Further characterization of grapevine leafroll disease, $\mathrm{p}$. 59-60. In: Rumbos, I.C., R. Bovey, D. Gonsalves, W.B. Hewitt, and G.P. Martelli (eds.). Proceedings of the 10th Meeting of the International Council for the Study of Viruses and Virus Diseases of the Grapevine. Plant Protection Institute, P.O.Box 303, 38001 Volos, Greece.

Hanna, E., M. Digiaro, T. Elbeaino, E. Choueriri, J. Jawahar, and G.P. Martelli. 2008. Incidence of viruses and nematode vectors in Lebanese vineyards. Journal of Phytopathology 156:304-310.

Herrera, M. 2000. Virus diseases in grapevine in the central zone of Chile. In: $4^{\circ}$ International Symposium on table grape. November 28-December 1. 2000. La Serena, Chile.
Latorre, B. 2004. Enfermedades de las plantas cultivadas. $6^{\text {a }}$ ed. ampliada. Pontificia Universidad Católica de Chile. Santiago, Chile. 638 pp.

Maeso, D. 2000. Estudios sobre la transmisión del virus del enrulamiento de la vid (GLRaV III) por el "chanchito blanco" (Planococcus ficus) en Uruguay. INIA Las Brujas. Actividades de Difusión $\mathrm{N}^{\circ}$ 243:29-40. 10/2000.

Mahfoudhi, N., M. Digiaro, and M. Habib Dhouibi. 2008. Incidence and distribution of grapevine leafroll-associated viruses in Tunisian vineyards. Journal of Phytopathology 156:556-558.

Martelli, G., N. Ghanem-Sabanadzovic, A. Agranovsky, M. Al Rwahnih, V. Dolja, C. Dovas, M. Fuchs, P. Gugerli, J. Hu, W. Jelkmann, N. Katis, V. Maliogka, M. Melzer, W. Menzel, A. Minafra, M. Rott, A. Rowhani, S. Sabanadzovic, and P. Saldarelli. 2012. Taxonomic revision of the family Closteroviridae with special reference to the grapevine leafroll-associated members of the genus ampelovirus and the putative species unassigned to the family. Journal of Plant Pathology 94:7-19.

Martelli, G.P., and E. Boudon-Padieu. 2006. Directory of infectious diseases of grapevines and viruses and virus-like diseases of the grapevine: Bibliographic Report 1998-2004. Options Méditerranéennes B55.

Martin, R., K. Eastwell, A. Wagner, S. Lamprecht, and I. Tzanetakis. 2005. Survey for viruses of grapevine in Oregon and Washington. Plant Disease 89:763-766.

Minafra, A., and A.Hadidi. 1994. Sensitive detection of grapevine virus A, B, or leafroll-associated III from viruliferous mealybugs and infected tissue by cDNA amplification. Journal of Virologicals Methods 47:175-187.

Pietersen, G. 2004. Spread of grapevine leafroll disease in South Africa - a difficult, but not insurmountable problem. Wynboer. Available online at: www. wynboer.co.za/recentarticles/0406leaf.php3 (Website accessed: November 14, 2011).

Rakhshandehroo, F., H. Pourrahim, H. Zamani Zadaeh, S. Rezaee, and M. Mohammadi. 2005. Incidence and distribution of viruses infecting 
Iranian Vineyards. Journal of Phytopathology 153:480-484.

Rapayati, N., M. Tefera, A. Olufemi, J. Sridhar, K. Gandhi, L. Gutha, and R. Martin. 2009. Current status of grapevine viruses in the Pacific Northwest vineyards of the United States. Highlights of the 16th Meeting of ICVG Dijon, France, 31 August - 4 September.

Rosciglione, B., and P. Gugerli. 1989. Transmission of grapevine leafroll disease and an associated closterovirus to healthy grapevine by the mealybug Planococcus ficus Signoret. p. 67-69. In: E. Tanne (ed.). Proceedings of the 9th Meeting of the International Council for the Study of Viruses and Virus Diseases of the Grapevine (ICGV), Kiryat Anavim, Israel, September 1987. The Volcani Center, P.O. Box 6, Bet Dagan 50250, Israel.

Rowhani, A., and D. Golino. 1995. ELISA test reveals new information about leafroll disease. Californian Agriculture 49:26-29.

SAG. 2010. Informe Ejecutivo: Catastro Vitícola Nacional 2008. Servicio Agrícola y Ganadero (SAG). Available online at: http://www.sag.gob. cl/OpenDocs/asp/pagDefault. asp?boton=Doc $52 \& \operatorname{argInstanciaId}=52 \& \arg$ CarpetaId $=1462 \& \mathrm{a}$ rgTree NodosAbiertos $=()(1462) \&$ argTree Nodo Actual=1462\&argTreeNodoSel=1462 (Website accessed June 17, 2010).

SAG. 2009. Catastro vitícola 2009. Servicio Agrícola y Ganadero (SAG). Available online at: http://www.sag.gob.cl/common/asp/ pagAtachadorVisualizador.asp?argCryptedDat $\mathrm{a}=$ GP1TkTXdhRJAS2Wp3v88hAhbS3OcMVF HR6XKPmjAB0k\%3D\&argModo=\&argOrigen= BD\&argFlagYaGrabados=\&argArchivold=28534 (Website accessed: September 10, 2010).

Sforza, R., V. Komar, and C. Greif. 2000. New scale insect vectors of grapevine closteroviruses. Extended Abstracts 13th Meeting of ICGV, Adelaide 2000, 14.

Sharma, A., J. Wang, S. Duffy, S. Zhang, M. Wong, A. Rashed, M. Cooper, K. Daane, and R. Almeida. 2011. Occurrence of grapevine leafroll-associated virus complex in Napa Valley. PLoS ONE 6(10):e26227. DOI: 10.1371/journal.pone.0026227.

Tanne, E., Y. Ben-Dov, and B. Raccah. 1989. Transmission of closterolike particles associated with grapevine leafroll by mealybugs (Pseudococcidae) in Israel. p. 71 - 73. In: E. Tanne (ed.). Proceedings of the 9th Meeting of the International Council for the Study of Viruses and Virus Diseases of the Grapevine (ICGV), Kiryat Anavim, Israel, September 1987. The Volcani Center, P.O. Box 6, Bet Dagan 50250, Israel.

Tsai, C., D. Bosco, K. Daane, and R. Almeida. 2011. Effect of host plant tissue on the vector transmission of grapevine leafroll-associated Virus 3. Entomological Society of America 104:1480-1485.

Vega, A., R. A. Gutierrez, A. Pena-Neira, G.R. Cramer, and P. Arce-Johnson. 2011. Compatible GLRaV-3 viral infections affect berry ripening decreasing sugar accumulation and anthocyanin biosynthesis in Vitis vinifera. Plant Molecular Biology 77: 261-274. 
